\title{
Parasitic Hymenoptera Recovered by DNA Barcoding of Malaise Trap Collection at the Chittagong University Campus, Bangladesh
}

\author{
Santosh Mazumdar, "*, Paul David Neil Hebert ${ }^{2}$, Badrul Amin Bhuiya ${ }^{3}$, Mohammed Ismail Miah ${ }^{1}$ \\ ${ }^{1}$ Department of Zoology, University of Chittagong, Chattogram, Bangladesh \\ ${ }^{2}$ Centre for Biodiversity Genomics, University of Guelph, Guelph, Canada \\ ${ }^{3}$ Biodiversity Research for Environmental Protection (BREP), Chattogram, Bangladesh
}

Email address:

mazumdarsantosh@gmail.com (S. Mazumdar), phebert@uoguelph.ca (P. D. N. Hebert), badrulbhuiyabrep@gmail.com (B. A. Bhuiya), ismail_cu@yahoo.com (M. I. Miah)

${ }^{*}$ Corresponding author

\section{To cite this article:}

Santosh Mazumdar, Paul David Neil Hebert, Badrul Amin Bhuiya, Mohammed Ismail Miah. Parasitic Hymenoptera Recovered by DNA Barcoding of Malaise Trap Collection at the Chittagong University Campus, Bangladesh. American Journal of BioScience.

Vol. 7, No. 6, 2019, pp. 94-98. doi: 10.11648/j.ajbio.20190706.12

Received: October 18, 2019; Accepted: November 12, 2019; Published: November 19, 2019

\begin{abstract}
In the natural ecosystems, parasitic Hymenoptera composes the most significant group of biocontrol agents. DNA barcode (658 bp sequence from the 5'-end of cytochromeoxidase I) analysis of hymenopterans collected in a Malaise trap in Chittagong university campus was performed to analyze the diversity of parasitic wasps. In the present study a total of 3,468 sequences were generated that represented 31 species, 83 genera and 22 families from seven superfamilies of Hymenoptera. Among them 25 species namely Aphanogmus fijiensis Ferriere, Telenomus remus Nixon, Ganaspis xanthopoda Ashmead, Encarsia sophia Girault \& Dodd, Copidosoma floridanum Ashmead, C. thebe Walker, Ceranisus menes Walker, Hemiptarsenus varicornis Girault, Eupelmus martellii Masi, Trichogramma achaeae Nagaraja and Nagarkatti, Trichogrammatoidea bactrae Nagaraja, Binodoxys acalephae Marshall, B. communis Gahan, Aspidobracon noyesi van Achterberg, Bracon crassicornis Thomson, Cardiochiles fuscipennis Szepligeti, Apanteles boaris Walker, Glyptapanteles creatonoti Viereck, Phaedrotoma depressa Li \& van Achterberg, Psyttalia fletcheri Silvestri, Aleiodes malichi Quicke \& Butcher, A. prillae Quicke \& Butcher, A. sutthisani Quicke \& Butcher, Diplazon orientalis Cameron, Exochus pictus Holmgren, 58 genera, 12 subfamilies and 7 named families specifically Megaspilidae, Figitidae, Eupelmidae, Ormyridae, Perilampidae, Torymidae and Trigonalyidae are the first reports from Bangladesh. The results of this study will be resulted to determining of parasitic hymenopteran fauna in Bangladesh.
\end{abstract}

Keywords: Parasitic Hymenoptera, Malaise Trap, DNA Barcode, Bangladesh

\section{Introduction}

Parasitic Hymenoptera are natural control agents for insects mainly in the terrestrial habitats. About one quarter [1] of the 150,000 described species of Hymenoptera are parasites [1-2]. DNA barcoding (658 bp sequence from the $5^{\prime}$ end of COI) is an effective method to identify animal species [3]. DNA barcoding of arthropods collected by Malaise traps has gained popularity for assessing terrestrial insect diversity [4], this method is leading to its frequent use in insect biodiversity assessments [5]. A study coupled Malaise trap and DNA barcoding to analyze the diversity of parasitic Hymenoptera in a sub-arctic environment [6]. In Bangladesh, the study of parasitic hymenopterans has been properly studied. The study presents a preliminary list of parasitic Hymenoptera that were collected by Malaise trap at the Chittagong university campus of Bangladesh and analyzed using DNA barcoding. Though rationally many more parasitic Hymenoptera still remain undescribed, present taxonomic work will be a reference for future work in Bangladesh. 


\section{Materials and Methods}

\subsection{Specimen Collection, Processing, Identification and Specimen Deposition}

A Townes-style Malaise trap (BioQuip Inc. USA) was installed at Chittagong University Campus (Lat. $22.46359^{\circ} \mathrm{N}$; Long. $91.7808^{\circ} \mathrm{E}$ ) in Bangladesh by following the Standard Operating Protocol for the Global Malaise Trap Program [7]. Insects were collected from March 2014 to February 2015. The samples were harvested weekly in a 500 $\mathrm{mL}$ plastic Nalgene bottle that was filled with $375 \mathrm{~mL}$ of $95 \%$ ethanol and placed in $500 \mathrm{~mL}$ of fresh ethanol before storage at $-20^{\circ} \mathrm{C}$ until analysis. Collected insects were analyzed, following standard barcoding protocols [8], at the Canadian Centre for DNA Barcoding within the Centre for Biodiversity Genomics, University of Guelph, Canada. Collection data, voucher information and taxonomy for each specimen are available in the Barcode of Life Data Systems [9]. All the specimens analyzed in this study have been curated at the Centre for Biodiversity Genomics, University of Guelph, Guelph, Ontario, Canada.

\subsection{Molecular Analysis and Data Analysis}

DNA extracts were prepared from a single leg from each large specimen and from the whole body of smaller taxa, and vouchers were recovered after DNA extraction for imaging and curation. Tissue lysis, DNA extraction, PCR amplification, cycle sequencing and sequence analysis were performed atthe Canadian Centre for DNA Barcoding following the standard protocols (CCDB). PCR amplification of COI-5' was performed with primers C_LepFolF and C_LepFolR [10] following PCR conditions; $94^{\circ} \mathrm{C}$ (1 min), 5 cycles at $94^{\circ} \mathrm{C}(40 \mathrm{~s}), 45^{\circ} \mathrm{C}(40 \mathrm{~s}), 72^{\circ} \mathrm{C}(1 \mathrm{~min}) ; 35$ cycles at $94^{\circ} \mathrm{C}(40 \mathrm{~s}), 51^{\circ} \mathrm{C}(40 \mathrm{~s}), 72^{\circ} \mathrm{C}(1 \mathrm{~min})$ and a final extension at $72^{\circ} \mathrm{C}(5 \mathrm{~min})$ and amplicons were sequenced using BigDye v3.1 (Applied Biosystems) on an ABI 3730XL. Sequences were assembled, aligned, and edited using CodonCode Aligner (CodonCode Corporation, USA) and submitted to Barcode of Life Data Systems (BOLD) [11]. With a few exceptions, by considering sequence matches to records on BOLD, the specimens with barcodes were assigned to 22 families of 8 superfamilies.

\section{Result}

Table 1 presents the parasitic hymenoptera from Bangladesh analyzed in this study. The specimens represent six superfamilies viz. Ceraphronoidea (1 species/1 genus), Diaprioidea (no species/1 genus), Platygastroidea (1 species/2 genera), Cynipoidea (1 species/1 genus), Chalcidoidea (10 species/28 genera), Ichneumonoidea (16 species/49 genera). In Evanioidea and Trigonalyidea only family Evaniidae and Trigonalyidae, respectively were confirmed.

Table 1. Parasitic Hymenoptera revealed by DNA barcoding of Malaise trap samples collected in Bangladesh.

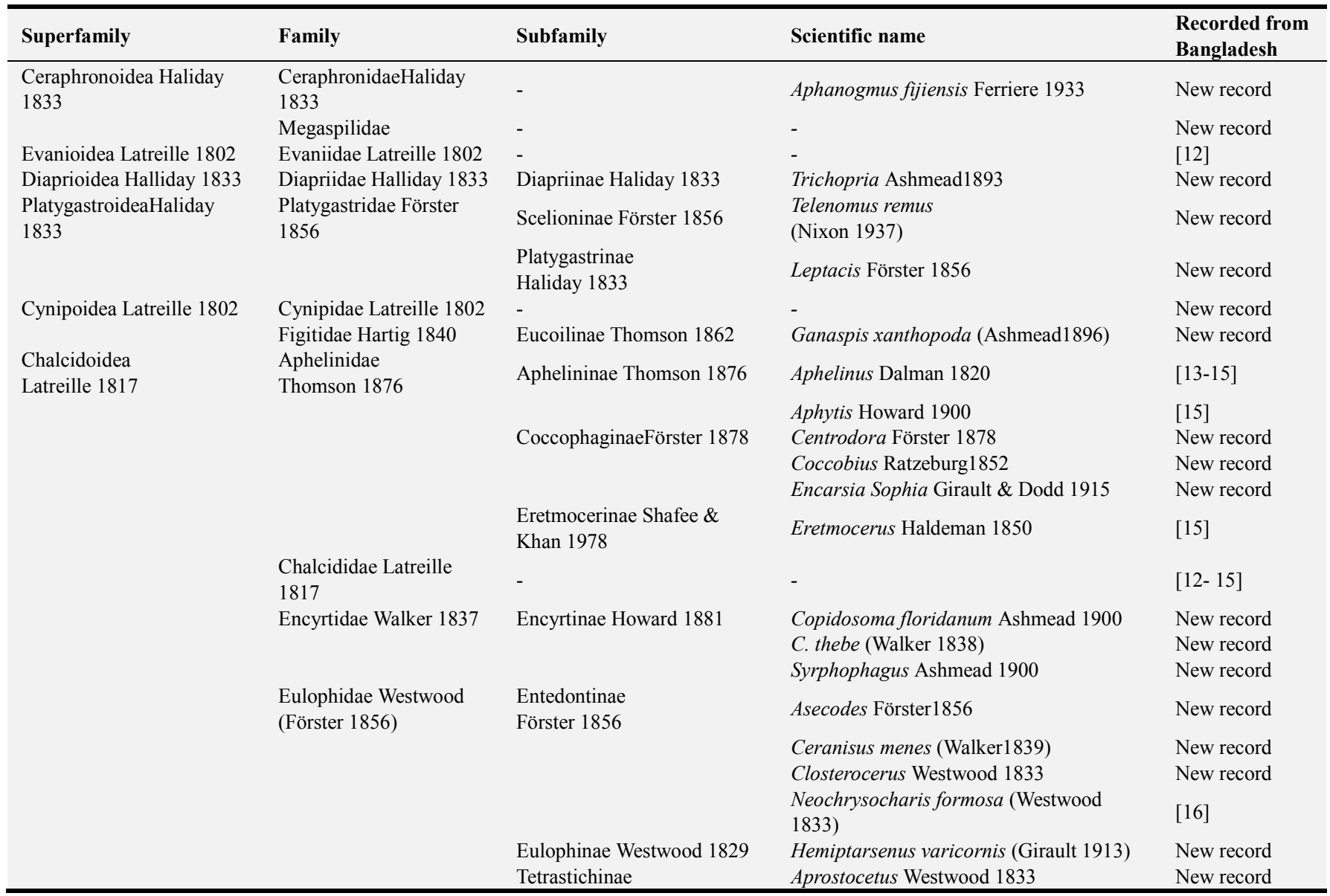




\begin{tabular}{|c|c|c|c|c|}
\hline Superfamily & Family & Subfamily & Scientific name & $\begin{array}{l}\text { Recorded from } \\
\text { Bangladesh } \\
\end{array}$ \\
\hline \multirow{56}{*}{$\begin{array}{l}\text { Ichneumonoidea Latreille } \\
1802\end{array}$} & \multirow{3}{*}{ Eupelmidae Walker 1833} & \multicolumn{3}{|l|}{ Graham 1987} \\
\hline & & $\begin{array}{l}\text { Eupelminae } \\
\text { Walker } 1833\end{array}$ & Anastatus Motschulsky 1859 & New record \\
\hline & & & $\begin{array}{l}\text { Eupelmus martellii Masi } 1941 \\
\text { Zaischnopsis } 1904\end{array}$ & $\begin{array}{l}\text { New record } \\
\text { New record }\end{array}$ \\
\hline & \multirow{10}{*}{$\begin{array}{l}\text { Eurytomidae Walker } \\
1832 \\
\text { Mymaridae Haliday } \\
1833\end{array}$} & - & 20 & [17] \\
\hline & & & Alaptus Westwood 1839 & New record \\
\hline & & & Anagrus Haliday 1833 & [18] \\
\hline & & & Anaphes Haliday1833 & [18] \\
\hline & & & Gonatocerus Nee 1834 & [19] \\
\hline & & & Lymaenon Walker 1846 & New record \\
\hline & & & Mymar Curtis 1829 & New record \\
\hline & & & Neomymar Crawford 1913 & New record \\
\hline & & & Omyomymar Schauff (1983) & New record \\
\hline & & & Stethynium Enock1909 & {$[18]$} \\
\hline & \multirow{8}{*}{$\begin{array}{l}\text { Ormyridae Förster } 1856 \\
\text { Perilampidae } \\
\text { Latreille } 1809 \\
\text { Pteromalidae } \\
\text { Dalman } 1820 \\
\text { Torymidae } \\
\text { Trichogrammatidae } \\
\text { Haliday1851 }\end{array}$} & - & - & New record \\
\hline & & & - & New record \\
\hline & & & & \\
\hline & & - & - & [20] \\
\hline & & - & - & New record \\
\hline & & - & $\begin{array}{l}\text { Trichogramma achaeae Nagaraja and } \\
\text { Nagarkatti } 1970\end{array}$ & New record \\
\hline & & - & T. chilonis Ishii 1941 & {$[21,22]$} \\
\hline & & - & $\begin{array}{l}\text { Trichogrammatoidea bactrae } \\
\text { Nagaraja1979 }\end{array}$ & New record \\
\hline & \multirow[t]{35}{*}{$\begin{array}{l}\text { Braconidae Latreille } \\
1829\end{array}$} & \multirow[t]{2}{*}{ Alysiinae Leach 1815} & Asobara Förster 1862 & New record \\
\hline & & & Dinotrema Förster 1862 & New record \\
\hline & & \multirow[t]{3}{*}{ Aphidiinae Haliday 1833} & Binodoxys acalephae (Marshall 1896) & New record \\
\hline & & & B. communis (Gahan 1926) & New record \\
\hline & & & Lipolexis oregmae (Gahan 1932) & [21] \\
\hline & & Brachistinae Förster 1862 & - & New record \\
\hline & & \multirow[t]{9}{*}{ Braconinae Nees 1811} & Aspidobracon noyesi van Achterberg 1984 & New record \\
\hline & & & Bracon crassicornis Thomson 1892 & New record \\
\hline & & & B. hebetor Say 1836 & {$[12,23]$} \\
\hline & & & Cratocnema Szépligeti 1914 & New record \\
\hline & & & Physaraia Shenefelt 1978 & New record \\
\hline & & & Plesiobracon Cameron (1903) & New record \\
\hline & & & Pycnobracon Cameron 1902 & New record \\
\hline & & & Syntomernus Enderlein 1920 & New record \\
\hline & & & Tropobracon Cameron1905 & {$[12,23]$} \\
\hline & & CardiochilinaeAshmead 1900 & Cardiochiles fuscipennis Szepligeti 1900 & New record \\
\hline & & Cheloninae Förster 1862 & Chelonus Panzer 1806 & {$[12,23]$} \\
\hline & & \multirow[t]{2}{*}{ Doryctinae Förster 1862} & Rhaconotus Ru 1854 & {$[12,23]$} \\
\hline & & & Spathius Nees 1818 & [23-24] \\
\hline & & \multirow{16}{*}{$\begin{array}{l}\text { Euphorinae Förster } 1862 \\
\text { Exothecinae Förster } 1862 \\
\text { Gnamptodontinae Fischer } \\
1970 \\
\text { Hormiinae Förster } 1862 \\
\text { Ichneutinae Förster } 1862 \\
\text { Lysiterminae Tobias } 1968 \\
\text { Microgastrinae } \\
\text { Förster } 1862\end{array}$} & - & New record \\
\hline & & & Shawania van Achterberg 1983 & New record \\
\hline & & & Gnamptodon Haliday 1833 & New record \\
\hline & & & Hormius Nees 1818 & New record \\
\hline & & & Paroligoneurus Muesebeck 1931 & New record \\
\hline & & & Pentatermus Hedqvist 1963 & New record \\
\hline & & & Apanteles boaris Walker & New record \\
\hline & & & Choeras Mason 1981 & New record \\
\hline & & & Cotesia Cameron 1891 & \\
\hline & & & Diolcogaster Ashmead 1900 & New record \\
\hline & & & Dolichogenidea Viereck 1911 & New record \\
\hline & & & Glyptapanteles & New record \\
\hline & & & Creatonoti (Viereck) & New record \\
\hline & & & Microplitis Förster 1863 & [12] \\
\hline & & & Neoclarkinella Rema \& Narendran 1996 & New record \\
\hline & & & Parapanteles Ashmead (1900) & New record \\
\hline
\end{tabular}




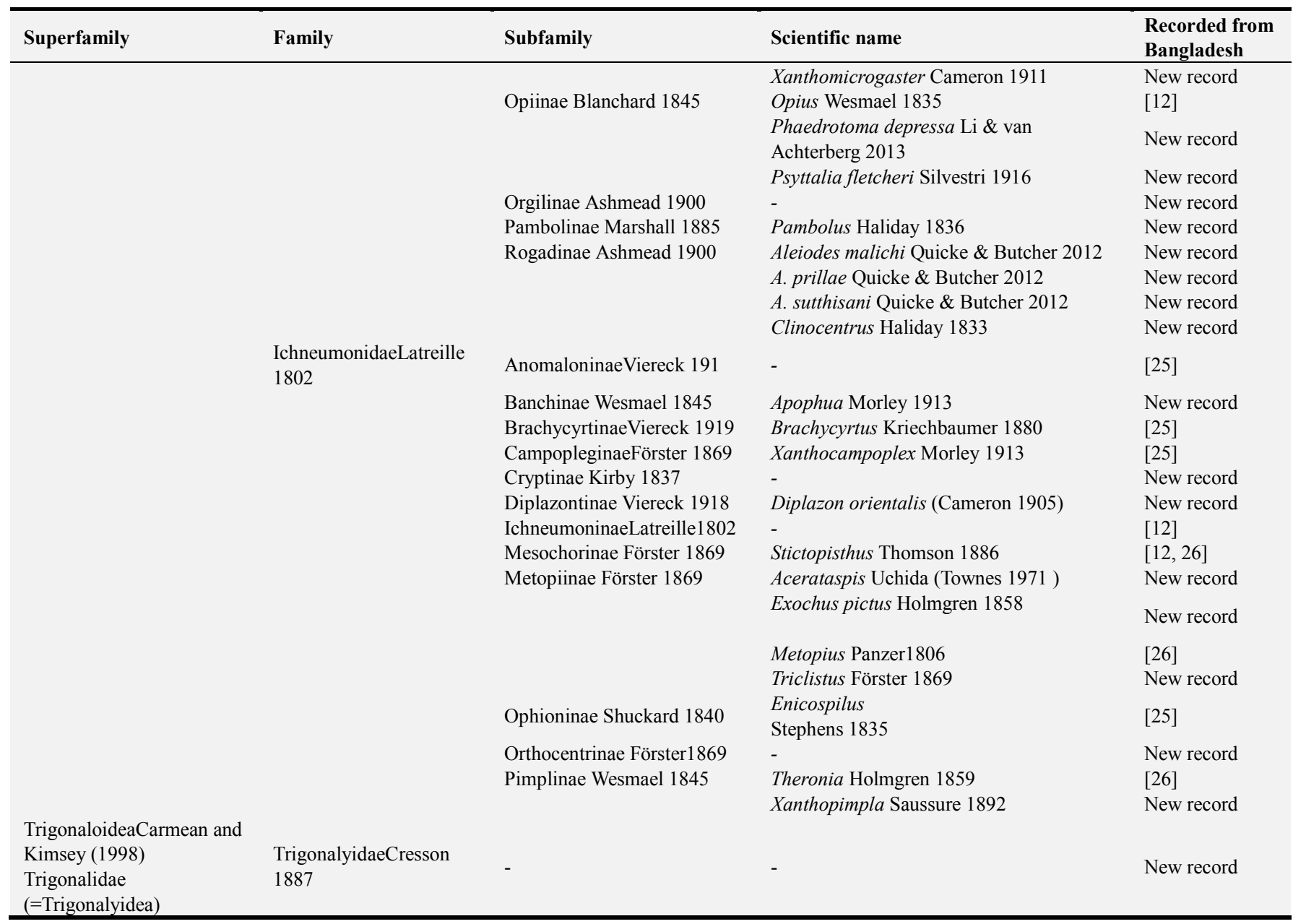

\section{Discussion}

In Bangladesh, Rahman provided a list of 34 species from 17 genera of braconid parasitoids from different crop pest [27]. Gapud compiled a list of 182 species of parasitic hymenopterans [12]. Miah et al. prepared a preliminary list of parasitic wasps of family Ichneumonidae representing 28 genera and 57 species under 9 subfamilies [25]. Ahmad et al. mentioned 236 species of Hymenoptera in their book [28]. Bhuiya and Miah listed 65 species under 2 subfamilies and 33 genera belonging to Encyrtidae [29]. Mazumdar et al. reported 72 species in 36 genera under 14 families of Hymenoptera [1]. Recently, Huber and Islam provided identification key to 10 species in 4 genera of the family Mymaridae [18]. Trichogramma spp. and Bracon hebetor are commercially reared and implemented in controlling various vegetable pests of Bangladesh [30]. In the present study, 25 species, 58 genera, 12 subfamilies, 7 families and 1 Superfamily have been newly recorded from Bangladesh.

\section{Conclusion}

This piece of work is the first extensive taxonomic work to explore the natural enemies present in Bangladesh. This taxonomic work will be an excellent reference for future work. On the basis of this work and with the addition of further works suitable biocontrol agents will be find out from parasitic Hymenoptera for uses in different sectors.

\section{Acknowledgements}

The authors are grateful to colleagues at the Centre for Biodiversity Genomics, University of Guelph, for aid with sequence analysis.

\section{Conflict of Interest Statement}

There are no conflicts of interest.

\section{References}

[1] Mazumdar, S., Hebert, P. D. N. and Bhuiya, B. A. (2015). Biodiversity study of Bangladeshi parasitoid wasps (Insecta: Hymenoptera) of Malaise trap collections using DNA barcoding techniques. Genome, 58: 254.

[2] Wisegeek (2015), www.wisegeek.org/how-many-species-ofinsect-are-re.htm

[3] Hebert, P. D. N., Ratnasingham, S. and Dewaard, J. R. (2003). Barcoding animal life: cytochrome coxidase subunit 1 divergences among closely related species. Proceedings of the Royal Society B: Biological Sciences, 270: 96-99. 
[4] deWaard, J. R., Levesque-Beaudin, V., deWaard, S. L., Ivanova, N. V., McKeown, J. T., Miskie, R., Naik, S., Perez, K. H., Ratnasingham, S., Sobel, C. N. and Sones, J. E. (2019). Expedited assessment of terrestrial arthropod diversity by coupling Malaise traps with DNA barcoding. Genome, 62 (3): 85-95.

[5] Ashfaq, M., Sabir, J. S., El-Ansary, H. O., Perez, K., Levesque-Beaudin, V., Khan, A. M., Rasool, A., Gallant, C., Addesi, J. and Hebert P. D. (2018). Insect diversity in the Saharo-Arabian region: Revealing a little-studied fauna by DNA barcoding. PLoS ONE, 13 (7): p.e0199965.

[6] Stahlhut, J. K., Fernández-Triana, J., Adamowicz, S. J., Buck, M., Goulet, H., Hebert, P. D. N., Huber, J. T., Merilo, M. T., Sheffield, C. S., Woodcock, T. and Smith, M. A. (2013). DNA barcoding reveals diversity of Hymenoptera \& dominance of parasitoids in a sub-arctic environment. BMC ecology, 13 (1): 2.

[7] www.dnabarcoding.ca.

[8] http://ccdb.ca/resources.php

[9] http://v3.boldsystems.org/index.php/TaxBrowser_Taxonpage ?taxid $=125$

[10] http://www.ccdb.ca/docs/CCDB_PrimerSets.

[11] www.boldsystems.org

[12] Gapud, V. P. (1992). Insect \& mite pests of plant crops in Bangladesh \& their enemies: a compendium. United States Agency for International Development/Bangladesh Agricultural Research Council/CHECCI \& Co. Consulting Inc.

[13] Ali, M. I., Karim, M. A. and Chowdhury, A. B. M. N. U. (1993). Natural enemies of cotton insect pests in Bangladesh. Journal of the Asiatic Society of Bangladesh, Science 19 (2): 155-161.

[14] Ali, M. I., Islam, M. I. and Kabir, S. M. H. (1995). Biological control of insect and mite pests in important agriculture crops of Bangladesh: A Review. Journal of the Asiatic Society of Bangladesh, Science 21 (2): 149-208.

[15] Bhuiya, B. A., Miah, M. I. and Mazumdar, S. (2014). A preliminary list of parasitic wasps (Hymenoptera: Chalcidoidea: Aphelinidae) of Bangladesh. Journal of Taxonomy and Biodiversity Research, 6: 13-15

[16] Mazumdar, S. and B. A. Bhuiya (2016). Parasitoids (Hymenoptera) of leafminer flies (Diptera: Agromyzidae) from Bangladesh. Journal of Threatened Taxa 8 (4): 87148718 .

[17] Catling, D. and Islam, Z.(2013). Diversity and seasonal fluctuations of arthropod fauna in Bangladesh deepwater rice. Bangladesh Rice Journal, 17 (1-2): 75-104.
[18] Huber, J. T. and Islam, N. (2017). Introduction to the Mymaridae (Hymenoptera) of Bangladesh. ZooKeys, (675): 75.

[19] Bhuiya, B. A. (1998). Two new species of Encyrtidae (Hymenoptera: Chalcidoidea) from Bangladesh attacking Pulvinaria psidii Maskell (Homoptera: Coccidae) on guava. Oriental Insects, 32 (1): 267-277.

[20] Bouček, Z. and Bhuiya, B. A. (1990). A new genus \& species of Pteromalidae (Hym.) attacking mealybugs \& soft scales (Hom. Coccidea) on guava in Bangladesh. Entomologists Monthly Magazine, 126: 231-235.

[21] Yu DSK. (2012). http://www.taxapad.com.(Accessed on 1810-2017).

[22] Chowdhury, Z. J., Alam, S. N., Dash, C. K., Maleque M. A. and Akhter A. (2016). Determination of parasitism efficacy and development of effective field release technique for Trichogramma spp. (Trichogrammatidae: Hymenoptera). American Journal of Experimental Agriculture, 10 (1): 1-7.

[23] Rahman, M. H. (2012). Systematic studies of parasitic wasp family Braconidae: (Insecta: Hymenoptera). LAP LAMBERT Academic Publishing, Germany.

[24] Habib, M. A, Hossain, M. A., Kabir, S. M. H. and Solhoy, T. (2001). Hymenopteran parasites (Arthropoda-Insecta) associated with mango orchard in Bangladesh. Dhaka University Journal of Biological Sciences, 10 (1): 84-94.

[25] Miah, M. I., Bhuiya, B. A. and Chowdhury, A. (1999). A preliminary list of parasitic wasps (Hymenoptera: Ichneumonidae) of Bangladesh. Bangladesh Journal of Entomology, 9 (1\&2): 61-67.

[26] Bhuiya, B. A., Miah, M. I. andJannat, A. (2005). Parasitic Hymenoptera (Chalcidoidea) of Moheshkhali, Cox's Bazar, Bangladesh. Bangladesh Journal of Zoology 32 (2): 9-15.

[27] Miah, M. I., Bhuiya, B. A. and Chowdhury, A. (2001). Valid names of previously recorded hymenopteran (Ichneumonidae) parasites of Bangladesh. Bangladesh Journal of Zoology, 29 (1): 103-106.

[28] Rahman, M.(1983). Kit totto, by Bangla Academy. Dhaka, Bangladesh.

[29] Ahmad, M., Kabir, S. M. H., Ahmed, A. T. A., Ahmed, Z. U., Begum, Z. N. T., Hassan, M. A. and Khondher, M. (Eds.) (2009). Encyclopedia of Flora and Fauna of Bangladesh, Vol. 22. Pterygota (Part). Asiatic Society of Bangladesh, Dhaka. pp. $5-131$.

[30] Bhuiya, B. A. and Miah, M. I. (2007). A preliminary list of parasitic wasps (Hymenoptera: Encyrtidae) of Bangladesh, Journal of Taxonomy and Biodiversity Research, 1 (1): 7-11.

[31] Upadhyay, D., Choudhary, D. and Singh, D. (2013). Instructional Manual On Biological Control Of Crop Pests \& Weeds:-Ent 507. 